\title{
Studies on Adsorption Removal of Odorous Pollutants (Acetaldehyde and Methyl Mercaptan) Adsorption of acetaldehyde on porous adsorbents
}

\author{
Seiki Tanada \\ Department of Public Health, School of Medicine, Tokushima University, Tokushima
}

\section{INTRODUCTION}

Acetaldehyde has recently been added to the list of chemicals in the control law for offensive odor in Japan, and its concentration in the atmosphere is limited by the law to the range of 0.05 to $0.5 \mathrm{ppm}^{1)}$. Acetaldehyde is emitted into the atmosphere particularly from the factories producing acetic acid, vinyl acetate, and chloroprene. It is well known that acetaldehyde irritates the mucous membrane of the eyes, nasal cavity, and pharynx ${ }^{2}$, and may be formed as a secondary pollutant by photochemical reactions in the atmosphere. Thus far, it has mainly been removed by a wet process $^{1)}$ and by catalytic decomposition with iodine ${ }^{3}$.

In my preceding paper ${ }^{4}$, I studied the adsorption removal of methyl mercaptan. The present report gives the data on the adsorption of acetaldehyde having the same monomethyl group as methyl mercaptan. Adsorption of acetaldehyde by 20 kinds of adsorbents (activated carbon, zeolite, and silicate) was examined by a static method to find some suitable adsorbents for the removal of acetaldehyde. The mechanism of adsorption of acetaldehyde on adsorbents is discussed on the basis of the application of Dubinin equation $^{5)}$ to adsorption isotherm and the pore size distribution.

\section{MATERIALS AND METHODS}

Materials: Acetaldehyde, commercially purified material, was purified by vacuum distillation. Activated carbon, zeolite, and silica gel used were commercial products, and magnesium silicate was prepared in our laboratory. Activated carbon Nos. $1 \sim 13$ were different kinds of adsorbents.

Measurements of amounts adsorbed and the rate of adsorption: The adsorbents were dried at $110^{\circ} \mathrm{C}$ for $1 \mathrm{hr}$ at $1 \times 10^{-2}$ Torr before using. The equilibrium amount of acetaldehyde adsorbed at $30^{\circ} \mathrm{C}$ and up to $60,000 \mathrm{ppm}$ was estimated from the stretching of a spring balance which became constant after the adsorption took place. The rate of adsorption was gravimetrically measured at the initial concentration about $90,000 \mathrm{ppm}$ and $30^{\circ} \mathrm{C}$, and expressed in a fractional approach to equilibrium ${ }^{6}$.

Measurement of pore size distribution: The pore size distribution of several adsorbents was obtained by the method of Dollimore and $\mathrm{Heal}^{7}$, the calculation being performed on a FACOM 203-28S (Fujitsu Co. Ltd.) computer using the FORTRAN program ${ }^{8}$.

\section{RESUlTS AND DISCUSSION}

Amount of acetaldehyde adsorbed: Table 1 shows the amount of acetaldehyde adsorbed on 20 kinds of adsorbents at $30^{\circ} \mathrm{C}$. The amount shown in Table 1 was obtained from the 
Table 1 Amount of acetaldehyde adsorbed on adsorbents at $30^{\circ} \mathrm{C}$

\begin{tabular}{|c|c|c|c|c|c|c|c|c|}
\hline \multirow{2}{*}{ No. } & \multirow{2}{*}{ Adsorbent } & \multicolumn{6}{|c|}{ Amount of acetaldehyde adsorbed $(\mathrm{mg} / \mathrm{g})$} & \multirow{2}{*}{ 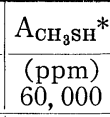 } \\
\hline & & $\begin{array}{c}\text { Equilib } \\
1,000\end{array}$ & $\begin{array}{l}\text { ium con } \\
5,000\end{array}$ & $\begin{array}{r}\text { centrati } \\
10,000\end{array}$ & $\begin{array}{l}\text { of of ace } \\
20,000\end{array}$ & $\begin{array}{l}\text { taldehyd } \\
40,000\end{array}$ & $\begin{array}{r}(\mathrm{ppm}) \\
60,000\end{array}$ & \\
\hline 1 & Activated carbon $(4 \sim 7 \mathrm{mesh})$ & 20.4 & 62.2 & 92.3 & 130.0 & 163.0 & 187.7 & 206.5 \\
\hline 2 & Activated carbon $(4 \sim 8$ mesh $)$ & 29.6 & 93.5 & 139.0 & 175.3 & 208.0 & 233.2 & 159.1 \\
\hline 3 & Activated carbon $(4 \sim 7 \mathrm{mesh})$ & 3.5 & 11.6 & 15.9 & 22.2 & 29.3 & 34.0 & 32.6 \\
\hline 4 & Activated carbon $(4 \sim 7 \mathrm{mesh})$ & 8.4 & 29.2 & 36.1 & 44.3 & 57.5 & 65.1 & 48.9 \\
\hline 5 & Activated carbon $(4 \sim 7 \mathrm{mesh})$ & 9.4 & 44.8 & 80.3 & 121.5 & 175.0 & 213.9 & 162.3 \\
\hline 6 & Activated carbon $(4 \sim 7 \mathrm{mesh})$ & 18.3 & 54.3 & 76.0 & 104.2 & 133.6 & 149. 4 & 115.1 \\
\hline 7 & Activated carbon $(4 \sim 7 \mathrm{mesh})$ & 18.2 & 34.8 & 60.7 & 95.3 & 140.3 & 168.5 & 133. 8 \\
\hline 8 & Activated carbon ( $7 \sim 9$ mesh) & 41.2 & 109.4 & 146.0 & 188.0 & 248.8 & 288.9 & 189.5 \\
\hline 9 & Activated carbon $(8 \sim 20 \mathrm{mesh})$ & 12.0 & 48.3 & 74.4 & 105.0 & 141.4 & 174.0 & 140.2 \\
\hline 10 & Activated carbon $(12 \sim 30 \mathrm{mesh})$ & 18.0 & 58.5 & 79.8 & 109.4 & 144.8 & 169.0 & 122.6 \\
\hline 11 & Activated carbon $(4 \sim 7 \mathrm{mesh})$ & 93.8 & 128.0 & 220.0 & 261.7 & 306.8 & 328.2 & 267. 0 \\
\hline 12 & Activated carbon ( $8 \sim 20 \mathrm{mesh})$ & 12.2 & 52.0 & 75.3 & 100.5 & 128.2 & 149.0 & 108.9 \\
\hline 13 & Activated carbon $(12 \sim 30 \mathrm{mesh})$ & 12.0 & 51.8 & 77.1 & 104.2 & 141.5 & 170.5 & 142.3 \\
\hline 14 & Synthetic zeolite A-3 ( $4 \sim 8$ mesh) & 60.0 & 92.6 & 98.5 & 102.8 & 107. 0 & 110.6 & 97.2 \\
\hline 15 & Synthetic zeolite F-9 ( $4 \sim 8$ mesh) & 75.2 & 125.2 & 133.1 & 136.7 & 138.0 & 138.8 & 104.5 \\
\hline 16 & Molecular sieve $5 \mathrm{~A}$ (1 $16 \mathrm{mesh})$ & 86.2 & 108.5 & 112.4 & 114.6 & 116.9 & 118.2 & 88.6 \\
\hline 17 & Molecular sieve $13 \mathrm{X}$ ( $1 \sim 16 \mathrm{mesh})$ & 110.0 & 139.0 & 143.7 & 147.3 & 150.5 & 153.0 & 90.0 \\
\hline 18 & Silicagel $(8 \sim 20 \mathrm{mesh})$ & 32.5 & 84.8 & 97.4 & 109.6 & 129.2 & 139.6 & 82.4 \\
\hline 19 & Magnesium silicate $(100 \sim 200 \mathrm{mesh})$ & 95.6 & 118.7 & 127.2 & 136.2 & 147.4 & 153.5 & 68.5 \\
\hline 20 & Magnesium silicate $(100 \sim 200 \mathrm{mesh})$ & 106.1 & 126.6 & 133.5 & 140.7 & 150.2 & 155.8 & 79.0 \\
\hline
\end{tabular}

* $\mathrm{A}_{\mathrm{CH}_{3} \mathrm{SH}}$ shows the amount of $\mathrm{CH}_{3} \mathrm{SH}$ adsorbed on adsorbents at a equilibrium concentration $60,000 \mathrm{ppm}$ adsorption isotherm at $30^{\circ} \mathrm{C}$ and up to $60,000 \mathrm{ppm}$. The higher the equilibrium concentration, the larger was the amount adsorbed on each adsorbent. Activated carbon No. 11, zeolite Nos. 14 17, and magnesium silicate Nos. 19 and 20 showed a larger amount adsorbed at lower concentrations of 1,000 and $5,000 \mathrm{ppm}$, while activated carbon No. 11 showed the largest adsorption among the twenty at a higher concentration of $60,000 \mathrm{ppm}$. The activated carbon No. 11 was found to be the most suitable adsorbent for the removal of acetaldehyde and methyl mercaptan with concentrations up to $60,000 \mathrm{ppm}$.

Application of Dubinin equation to adsorption isotherm: In general, adsorbents contain pores of various sizes, and adsorption properties of an adsorbent are intimately associated with its porous structure, the

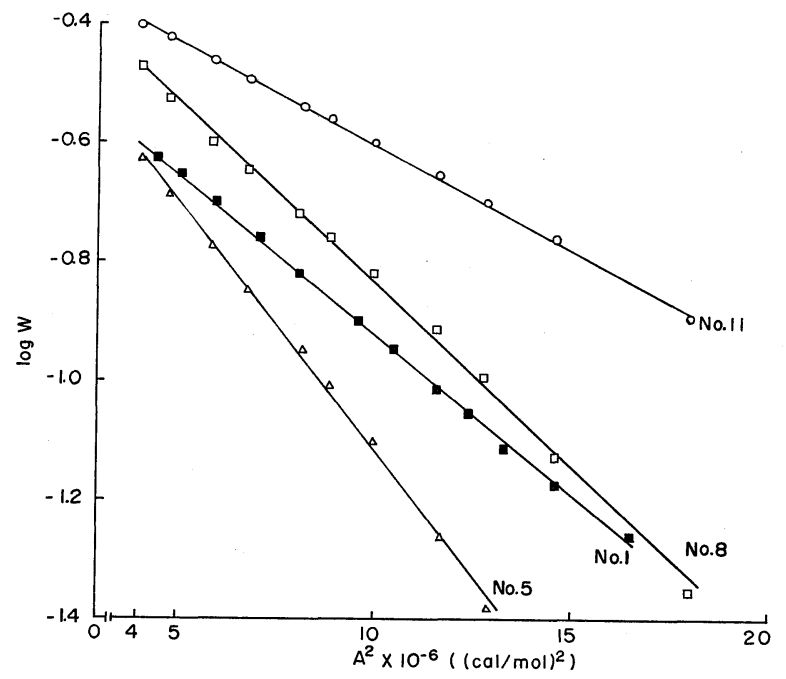

Fig. 1 Application of Dubinin equation to adsorption isotherms of acetaldehyde on activated carbon (1-Adsorption isotherm of methyl mercaptan) 
smallest pores (micropores) playing the principal role in adsorption. Dubinin ${ }^{5)}$ proposed, for the theory of gas adsorption by microporous adsorbents, the following equations which represent the development of Polanyi's potential theory of adsorption.

$$
\begin{aligned}
& A=R T \ln \left(P_{s} / P\right) \\
& W=W_{0}\left[\exp \left(-\kappa_{0} A^{2}\right)\right]
\end{aligned}
$$

where $A$ is the decrease of free energy in adsorption, $R$ the gas constant, $T$ the absolute temperature, $P s$ the saturated vapor pressure, $P$ the equilibrium pressure, $W$ the filled volume of the adsorption space, $W_{0}$ the limiting volume of the adsorption space, and $\kappa_{0}$ is the constant. The theory of physical adsorption of a gas in micropores which he proposed is termed the theory of the volume filling of micropores. Fig. 1 shows the application of Dubinin equation to adsorption isotherms of acetaldehyde on several kinds of activated carbon. A plot of $\log W$ versus $A^{2}$ of each adsorbent gave a straight line. Dubinin equation can be applied to adsorption isotherms of acetaldehyde on activated carbon Nos. 5, 8 and 11, and it was therefore concluded that adsorption of acetaldehyde in micropores of activated carbon resulted in their volume filling.

Rate of adsorption: The rate of adsorption is one of the parameters required in choosing a suitable adsorbent for practical use and, therefore, the fractional approach to the equilibrium of acetaldehyde on adsorbent is shown in Table 2. The fractional approach to the equilibrium $^{6)}$ is given by

$$
E=q / q_{\infty}
$$

where $E$ is the fractional approach to the equilibrium, $q$ the amount adsorbed at various elapsed periods, and $q_{\infty}$ is the equilibrium amount adsorbed. It is thought that the longer the period at $E=0.5$ and $E=0.9$, the faster will be the rates of adsorption. Adsorption to approach $E=0.5$ was completed within about 3 min, except Nos. 14 and 15 but adsorbents Nos. 3, 8, 11, 14, 15 and 18 took a long time to approach $E=0.9$ and, in particular, adsorbents Nos. 14 and 15 took about $35 \mathrm{~min}$.

Table 2 Fractional approach to equilibrium of acetaldehyde on adsorbents

\begin{tabular}{r|r|r||r|r|r}
\hline \multirow{2}{*}{ No.* } & \multicolumn{2}{|c|}{ Time (min) } & \multirow{2}{*}{ No.*. } & \multicolumn{2}{c}{ Time (min) } \\
\cline { 2 - 5 } & $E=0.5$ & $E=0.9$ & & $E=0.5$ & $E=0.9$ \\
\hline 1 & 1.0 & 3.4 & 11 & 1.9 & 12.0 \\
2 & 1.7 & 5.9 & 12 & 0.9 & 3.0 \\
3 & 2.5 & 13.1 & 13 & 1.1 & 3.9 \\
4 & 1.6 & 4.3 & 14 & 7.5 & 34.4 \\
5 & 0.8 & 2.8 & 15 & 5.3 & 30.0 \\
6 & 1.6 & 5.1 & 16 & 1.6 & 7.2 \\
7 & 1.2 & 4.1 & 17 & 1.4 & 4.1 \\
8 & 2.0 & 14.2 & 18 & 3.2 & 16.9 \\
9 & 1.2 & 4.4 & 19 & 1.0 & 3.5 \\
10 & 1.1 & 3.8 & 20 & 1.7 & 5.9 \\
\hline
\end{tabular}

* No. 1 No. 13: Activated carbon

No. 14 No. 17: Zeolite

No. $18 \sim$ No. 20: Silicate The rate of adsorption on activated carbon No. 11 was relatively fast and therefore, this is suitable for practical purposes.

Pore size distribution and the relation between the amount adsorbed and the pore volume: The pore size distributions in the range of radii 6.5 to $300 \AA$ was obtained in this experiment and Fig. 2 shows them particularly in the range of 6.5 to $24.5 \AA$ to clarify the microporous structures of adsorbents. The curves except No. 5 rose to the constant volume at the radius of about $11 \AA$, and their volume was approximately constant in the range of 11 to $24.5 \AA$.

In general, adsorbents contain a variety of pore sizes but the results of Fig. 2 indicated that the micropore volumes at radii of less than about $11 \AA$ occupied most of the pore volume up to $24.5 \AA$. It has previously been found in this laboratory that the amount of gas adsorbed on adsorbents was mainly determined by its pore volume ${ }^{4,9}$. Table 3 shows the amount of acetaldehyde adsorbed and the pore volume of several adsorbents. If it is 


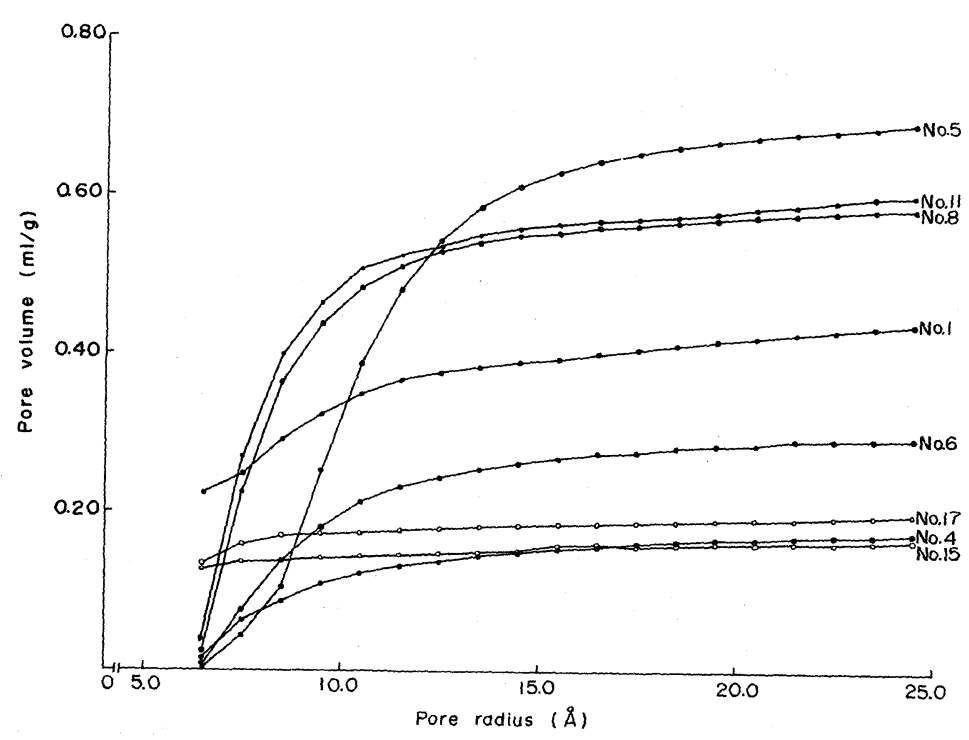

Fig. 2 Pore size distributions of several adsorbents

Table 3 Amount of acetaldehyde adsorbed and pore volume of several adsorbents

\begin{tabular}{c|c|c|c}
\hline No. & $\begin{array}{c}\text { Amount adsorbed } \\
\text { at } \\
60,000 \mathrm{ppm} \\
(\mathrm{mmol} / \mathrm{g})\end{array}$ & \multicolumn{2}{|c|}{ Pore volume $(\mathrm{ml} / \mathrm{g}$ ) } \\
\cline { 3 - 4 } & 4.26 & $0.550 \AA$ & $\mathrm{r} \leqq 10.5 \AA$ \\
\hline 1 & 1.48 & 0.2230 & 0.3495 \\
5 & 4.86 & 0.7898 & 0.1233 \\
5 & 3.39 & 0.3468 & 0.2117 \\
6 & 6.56 & 0.6500 & 0.4839 \\
8 & 7.77 & 0.6580 & 0.5575 \\
11 & 2.36 & 0.1685 & 0.1405 \\
14 & 3.15 & 0.2236 & 0.1465 \\
15 & 3.47 & 0.2497 & 0.1744 \\
17 & & & \\
\hline
\end{tabular}

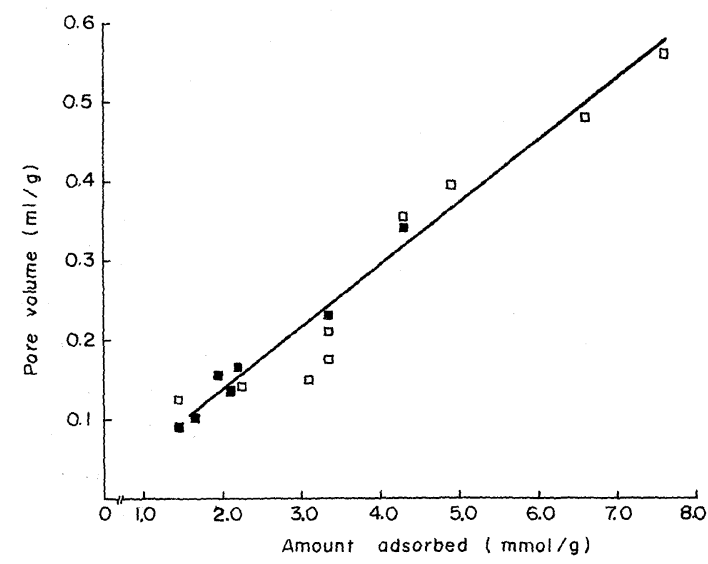

Fig. 3 Amount adsorbed versus pore volume $(\square-\square$ : Acetaldehyde, mercaptan)

assumed that the amount adsorbed on adsorbents is determined by their pore volume at radii of less than $300 \AA$, then the pore volume of Nos. 8 and 11 is estimated to be greater than that of No. 5 , but the present results shown in Table 3 was contrary to their pore volume. The relation between the amount adsorbed and the pore volume in the range of 6.5 to $10.5 \AA$ is illustrated in Fig. 3. An approximately linear relationship existed between the two and, therefore, it was confirmed that the amount adsorbed on adsorbents was determined by their micropore volume in the range of 6.5 to $10.5 \AA$. Amoore ${ }^{10)}$ reported that the length and the width of acetaldehyde were 4.0 and $2.5 \AA$, respectively. Adsorption of acetaldehyde in the micropores of adsorbents can be explained on the basis of its molecular size. The results of well suited application of Dubinin equation to adsorption isotherm and Fig. 3 indicate that adsorption of acetaldehyde in micropores $(r<10.5 \AA)$ of adsorbents resulted in their volume filling. 


\section{SUMMARY}

The amount of acetaldehyde adsorbed and the rate of adsorption on 20 kinds of adsorbents were examined at $30^{\circ} \mathrm{C}$. Activated carbon No. 11 was the most suitable adsorbent for the removal of acetaldehyde because of its higher adsorption capacity and faster rate of adsorption. The fact that Dubinin equation can be applied to adsorption isotherm of acetaldehyde indicated that adsorption of acetaldehyde in micropore resulted in volume filling. It was considered that the amount of acetaldehyde adsorbed on adsorbents was determined by their pore volume at radii of less than $10.5 \AA$ rather than by their pore volume in the range of radii of 6.5 to $300 \AA$.

Acknowledgement: The author is indebted to professor T. Miyoshi for his continuous guidance and his review of this manuscript. An abstract of this report was presented at the 35th Japanese Society of Public Health in Gifu City in October, 1976.

\section{REFERENCES}

1) Futabin, H.: Fundamental information on pollution word, Kogai To Taisaku, 12, 1415 (1976) (in Japanese).

2) Painter, D. E.: “Air Pollution Technology”, p. 25-38, Reston Publishing Co., Reston, Virginia (1974).

3) Summer, W.: “Methods of Air Deodorization”, p. 186-190, Elsevier Publishing Co., London and New York (1963).

4) Tanada, S.: Studies on the adsorption removal of methyl mercaptan gas, J. Shikoku Public Health, 19(2), 57-75 (1974) (in Japanese).

5) Dubinin, M. M.: Porous structure and adsorption properties of active carbons, Chem. Phys. Carbon, 2, 51-120 (1967).

6) Dryden, C. E. and Kay, W. B.: Kinetics of batch adsorption and desorption, Ind. Eng. Chem., 46, 2294-2300 (1954).

7) Dollimore, D. and Heal, G. R.: An improved method for the calculation of pore size distribution from adsorption data, J. Appl. Chem., 14, 109-114 (1964).

8) Boki, K.: Static and dynamic adsorption characteristics of hydrogen sulfide in gaseous phase on porous activated carbons and zeolites, Jap. J. Hyg., 32, 482-493 (1977) (in Japanese).

9) Miyoshi, T., Tanada, S. and Boki, K.: Properties of thirteen kinds of adsorbents for removal of hydrogen sulfide, methanethiol, methyl sulfide, trimethylamine and ammonia, Jap. J. Ind. Health, 19, 2-7 (1977).

10) Amoore, J. E.: The stereochemical theory of olfaction. 2. Elucidation of the stereochemical properties of the olfactory receptor sites, Proc. Sci. Sect. Toilet Goods Assoc., No. 37, 13-23 (1962). 


\title{
悪臭物質（アセトアルデヒド，メチルメルカプタン） の吸着除去に関する研究 多孔性吸着剂に対するアセトアルデヒドの吸着
}

\author{
棚田成紀 \\ 徳島大学医学部公衆衛生学教室 \\ (指導 : 三好 保教授)
}

近年, 覀臭防止法に加えられたアセトアルデヒドの除去に適した吸着剤を見い出し, さらに吸着機構を明らか にするため, 多孔性吸着剤 20 種（活性炭 13 種, ゼオライト 4 種, ケイ酸塩 3 種）に対するアセトアルデヒドの吸 着量と吸着速度を静的方法により測定した。

吸着剤 20 種のうち, 活性炭 No. 11 は平衡濃度 $1,000 \sim 60,000$ ppm の範囲内で吸着量が最も多く, 吸着速度は 比較的速いため, アセトアルデヒドの吸着除去剂に適している。若干の活性炭に対するアセトアルデデドの吸着 等温線はDubinin 式によく適合するてとから，アセトアルデヒドの吸着は活性炭のミクロ孔内への volume filling によって行われるものと考えられる。窒素ガス吸着法によって, 若干吸着剤の細孔半径 $300 \AA ̊$ 以下の細孔分布を 求めたが, いずれの吸着剤む半径約 $15 \AA ̊$ 以下 (ミクロ孔)の細孔が発達していた。さらに吸着量と細孔容積の関 係について検討した結果，アセトアルデヒドの吸着量と細孔半径 $10.5 \AA$ 以下の 細孔容積 との間に相関性が認め られた。したがってアセトアルデヒドの吸着剤はミクロ孔，とくに半径 $10.5 \AA$ 以下の細孔容積の大きいすのが 適していることがわかった。 